\title{
An Analysis of Liberal Feminism with Reference to Legal Equality \& Political Awareness in Different Universities of Chhattisgarh
}

\author{
Sujeet Kumar Mishra ${ }^{1, *}$, Amrita Bohra ${ }^{2}$ \\ ${ }^{1}$ Department of Education, Guru Ghasidas Vishwavidyalaya (A Central University) Bilaspur (C.G)-495009 \\ ${ }^{2}$ Education Department, M.I.M.T., Greater Noida, (U.P.) \\ *Corresponding author: sujeetmishraedu@gmail.com
}

Received July 29, 2019; Revised August 30, 2019; Accepted September 19, 2019

\begin{abstract}
Liberal Feminism focuses on women's ability to maintain their equality through their own activities and choices. Liberal feminists accept that due to different superstitions and orthodox women are not getting equal status. The purpose of this study is to find out the difference among the Universities (Central, State and Private) with reference to Legal Equality and political awareness. Researcher used survey method to collect the data for this study and randomly (disproportionate) selected 335 girl students girl students from all the three Universities. A selfdeveloped tool Feminism Reflection Inventory (F.R.I) is used in this study and researcher has taken two dimension of Liberal Feminism which is legal equality and political awareness for this study. It was found that legal equality in Liberal Feminism in girl students of Central, State and Private university are differ from each other while there is no significant difference in the reflection of Political Awareness as dimension of Liberal Feminism among the girl students of Central, State and Private Universities.
\end{abstract}

Keywords: liberal feminism, legal equality, political awareness, post graduate girl students, central university, state university and private universities

Cite This Article: Sujeet Kumar Mishra, and Amrita Bohra, "An Analysis of Liberal Feminism with Reference to Legal Equality \& Political Awareness in Different Universities of Chhattisgarh.” American Journal of Educational Research, vol. 7, no. 9 (2019): 640-643. doi: 10.12691/education-7-9-6.

\section{Introduction}

Education is the most important and powerful tool of social change. Dr Radhakrishnan has termed education as a social change. He has said that work that is normally done by family, religion, social and religious institutions in the society, is today done by educational institutions. We can change the thinking of people by education and can effect progress of society [1].

Education, as organised and imparted, can be classified as formal, non-formal and informal. Formal education implies modification of behaviour through an organised system of education. This type of education is imparted in the schools, colleges and universities. When we see education system of India it is divided into three levels namely primary, secondary and higher. Higher education includes college, universities and professional/specialised knowledge qualification in the form of graduate, post graduate and doctoral degree in many disciplines.

In despite of gender disparities in fact the women's education is increasing in present scenario. Today women are also rapidly raising their qualifications. The young women of India often have a higher level of education than their father and mother [2].
Women enrolment in higher education which was less than $10 \%$ of the total enrolment on the eve of Independence has risen to $41.5 \%$ in the academic year $2010-11$. Out of 169.75 lakh students enrolled in higher education in 2010-11, almost 70.49 lakh were women as compared to just about 47.08 lakh women enrolled in 2006-07 reveals the University Grant Commission (UGC) report (http:// times of india.india times.com/home/education/).

With growth in educational qualification of women, they are thinking about their rights and developing a new ideology. Educated women are expecting equal opportunity in each and every field. This ideology is known as feminism. Feminism is a doctrine suggesting that women are systematically disadvantaged in the modern society and advocating equal opportunities for men and women [3].

Social inequality leads to conflict as disadvantaged groups struggled to improve their power and status in society. This too is true in the case of sex roles. In the United States and many other societiesthroughout the world (particularly those with higher level of industrialization) one of the major social change of recent decades has been emergence of feminism on a large scale. Feminism can be defined as a social movement and ideology in the support of idea that a large share of scarce resources (Wealth, income, power, status) should go to 
women. The governing principles of feminism are that women should enjoy the same rights in the society as men and they should share equally in society's opportunities and scarce resources.

This movement is generally begun with 1848 meeting in Seneca Fally, New York. For the next 70 years the major objective of this movement was to obtain the right to vote for women (Only men were allowed to vote in National election in the United States). This is known as first wave Feminism in which suffrage battle was won. Second wave of feminism emerged in the 1960's to 1970's and eventually spread throughout the Western world in the United States the movement lasted through the early 1980's. Second wave feminism broadened the debate to a wide range of issue: sexuality, family, work place, reproductive rights and official legal inequalities with intra families disputes of feminism sex wars over issues such as sexuality and pornography, this wave of feminism failed. Third wave of feminism was started in the mid 1990's and continuing to the present. It was started due to the failure of second wave feminism during 1960's, 1970's and 1980's and realization that women are of many colours, ethnicities, nationalities, religion and cultural background. Third wave theory usually incorporates queer theory, anti-racism and women of colour consciousness, womanism, girl power etc. [4].

Liberal feminism emphasises equality of gender and also believes that women are also human, not only sex object. Liberal feminist argue that society holds the false belief that women are by nature, less intellectually and physically capable than men; thus it tends to discriminate against women in the academy, the forum and the marketplace. Earlier in late 1800 and 1900 the main aim of Liberal feminist was to gain the right to vote because they thought that it was the only way to access equality, liberty etc. Liberal Feminism focuses on women's ability to maintain their equality through their own activities and choices.

\section{Objectives}

1. To study the Legal Equality as a dimensions of liberal feminism among the girl students of Centre, State and Private University.

2. To study the Political Awareness as a dimensions of liberal feminism among the girl students of Centre, State and Private University.

\section{Hypothesis}

1. If the Liberal Feminism measured through Feminism Reflection Inventory (F.R.I.) then there is no significant difference in the reflection of Legal Equality as dimension of Liberal Feminism among the girl students of Central, State and Private Universities.

2. If the Liberal Feminism measured through Feminism Reflection Inventory (F.R.I.) then there is no significant difference in the reflection of Political Awareness as dimension of Liberal
Feminism among the girl students of Central, State and Private Universities.

\section{Methodology}

\subsection{Method}

For this study researcher used survey method to collect the data.

\subsection{Sample}

\begin{tabular}{|l|c|}
\hline Institutions & No. of PG Girl Students \\
\hline 1. Guru Ghasidas Vishwavidyalaya Bilaspur & 76 \\
\hline 2. Bilaspur University & 93 \\
\hline 3. Bilasa Girls Degree College Bilaspur & 84 \\
\hline 4. Dr. C.V. Raman University Bilaspur & 82 \\
\hline Total & 335 \\
\hline
\end{tabular}

\section{Tools}

Researcher used a self-developed tool i.e. Feminism Reflection Inventory (F.R.I.). For this study researcher has taken two dimensions of Liberal Feminism which are Legal Equality and Political Awareness. The items related to Legal Equality and Political Awareness are as follows:-

\begin{tabular}{|l|l|}
\hline Legal Equality & \multicolumn{1}{|c|}{ Political Awareness } \\
\hline $\begin{array}{l}\text { 1. I feel bad when my family members give } \\
\text { more importance to my brother. }\end{array}$ & $\begin{array}{l}\text { 2. I know all political } \\
\text { parties and political } \\
\text { leaders. }\end{array}$ \\
\hline $\begin{array}{l}\text { 6. I don't think that some particular subjects } \\
\text { (like maths) are for boys and some } \\
\text { particular subjects (like home science) are } \\
\text { for girls. }\end{array}$ & $\begin{array}{l}\text { 7. I like political } \\
\text { discussions. }\end{array}$ \\
\hline $\begin{array}{l}\text { 11. Generally I feel better when the no. of } \\
\text { boys and girls is equal in my class. }\end{array}$ & $\begin{array}{l}\text { 12. I want to participate } \\
\text { in politics to improve } \\
\text { politics of India. }\end{array}$ \\
\hline $\begin{array}{l}\text { 16. I don't believe that women's are } \\
\text { physically and mentally weaker than men. }\end{array}$ & \begin{tabular}{l} 
17.I like voting. \\
\hline 21. I get equal pocket money to my brother \\
22. I think vote is the \\
in democratic society.
\end{tabular} \\
\hline $\begin{array}{l}\text { 26. I want equal educational opportunities as } \\
\text { my brother is getting. }\end{array}$ & $\begin{array}{l}\text { 27. I vote according to } \\
\text { my personal views. }\end{array}$ \\
\hline
\end{tabular}

\section{Delimitations}

1. Marxist feminism and Radical Feminism are not taken by the researcher.

2. In Liberal Feminism participation in organisation, leadership and freedom dimensions are not used by the researcher.

3. UG girl students of Guru Ghasidas Vishwavidyalaya, Bilaspur University, Bilasa Girls Degree College and Dr. C.V. Raman University are not taken by the researcher. 


\section{Analysis and Interpretation}

When the first objective of the study is analysed through ANOVA, between group variance and within group variance is calculated and after that F-ratio is calculated it is shown in Table 1.

Table 1. Difference in Legal Equality among the girl students of Central State and Private University

\begin{tabular}{|c|c|c|c|c|c|}
\hline Source & df & $\begin{array}{c}\text { Sum of } \\
\text { Squares } \\
\text { (SS) }\end{array}$ & $\begin{array}{c}\text { Mean } \\
\text { Square } \\
\text { (MS) }\end{array}$ & $\begin{array}{c}\mathbf{F} \\
\text { Ratio }\end{array}$ & $\begin{array}{l}\text { Table value } \\
\text { at .o5 level of } \\
\text { significance }\end{array}$ \\
\hline Between Group & 2 & 27.578 & 13.789 & \multirow{3}{*}{9.374} & \multirow{3}{*}{3.02292} \\
\hline Within Group & 332 & 488.380 & 1.471 & & \\
\hline Total & 334 & 515.958 & & & \\
\hline
\end{tabular}

Table 1 indicates that when the Legal Equality in Liberal Feminism is measured by Feminism Reflection Inventory (F.R.I) then F-value is 9.374 and table value is 3.022 at .05 level, which is significant. It means research hypothesis 1 is accepted. It is clearly found that legal equality in Liberal Feminism in girl students of Central, State and Private university are differ from each other. To know which mean (Central- State or Central-Private or State-Private) are significantly different from each other, therefore the result of Post Hoc is analysed for the same.

Table 2 shows the multiple comparison tables which reflects the differences between individual groups and from this table researcher concludes that -

- Girl students of Central and State University are significantly different from each other in the reflection of Legal Equality in Liberal Feminism.

- Girl students of State and Private University are significantly different from each other in the reflection of Legal Equality in Liberal Feminism.

- While there is no significant difference between the girl students of Central and Private University in the reflection of Legal Equality in Liberal Feminism.

After analysis of post-hoc test, only Central and Private University are not significantly different from each other while Central- State, State- Private are significantly different from each other.
When the second objective of the study is analysed through ANOVA, between group variance and within group variance is calculated and after that F-ratio is calculated it is shown in Table 3.

Table 3 indicates that when thePolitical Awareness in Liberal Feminism is measured by Feminism Reflection Inventory (F.R.I) then F-value is1.424 and table value is 3.02292 at .05 level, which is not significant. It means research hypothesis 2 is rejected. It is clearly found that Political Awareness in Liberal Feminism in girl students of Central, State and Private University are not differing from each other.

It means when the Liberal Feminism measured through Feminism Reflection Inventory (F.R.I.) then there is no significant difference in the reflection of Political Awareness as dimension of Liberal Feminism among the girl students of Central, State and Private Universities.

\section{Findings}

1. When the Liberal Feminism measured through Feminism Reflection Inventory (F.R.I.) then there is difference in the reflection of Legal Equality as a dimension of Liberal Feminismamong the girl students of Central, State and Private Universities. To know which University girl students are significantly different from each other, therefore Post Hoc test is analysed for the same and it was found that

- Girl students of Central and State University are significantly different from each other in the reflection of Legal Equality.

- Girl students of State and Private University are significantly different from each other in the reflection of Legal Equality.

- While there is no significant difference between the girl students of Central and Private University in the reflection of Legal Equality.

2. When the Liberal Feminism measured through Feminism Reflection Inventory (F.R.I.) then there is no significant difference in the reflection of Political Awareness as dimension of Liberal Feminism among the girl students of Central, State and Private Universities.

Table 2. Mean Difference table of Legal Equality among the girl students of Central, State and Private University

\begin{tabular}{|c|c|c|c|c|c|c|}
\hline \multirow{2}{*}{$\begin{array}{c}\text { (I) } \\
\text { University }\end{array}$} & \multirow{2}{*}{$\begin{array}{c}(\mathrm{J}) \\
\text { University }\end{array}$} & \multirow{2}{*}{$\begin{array}{l}\text { Mean Difference } \\
\text { (I-J) }\end{array}$} & \multirow{2}{*}{ Std. Error } & \multirow{2}{*}{ Sig. } & \multicolumn{2}{|c|}{ 95\% Confidence Interval } \\
\hline & & & & & Lower Bound & Upper Bound \\
\hline \multirow{2}{*}{ Central } & Private & .26829 & .19312 & .348 & -.1864 & .7229 \\
\hline & State & $.68362^{*}$ & .16633 & .000 & .2920 & 1.0752 \\
\hline \multirow{2}{*}{ State } & Central & $-.68362^{*}$ & .16633 & .000 & -1.0752 & -.2920 \\
\hline & Private & $-.41532^{*}$ & .16202 & .029 & -.7968 & -.0339 \\
\hline \multirow{2}{*}{ Private } & Central & -.26829 & .19312 & .348 & -.7229 & .1864 \\
\hline & State & $.41532^{*}$ & .16202 & .029 & .0339 & .7968 \\
\hline
\end{tabular}

Table 3. Difference in Political Awareness among the girl students of Central, State and Private University

\begin{tabular}{|l|c|c|c|c|c|}
\hline Source & df & Sum of Squares (SS) & Mean Square (MS) & F Ratio & Table value \\
\cline { 1 - 4 } Between Group & 2 & 4.444 & 2.222 & 1.424 \\
\cline { 1 - 4 } Within Group & 332 & 518.284 & 1.561 & 3.02292 \\
\hline Total & 334 & 522.728 & & \\
\hline
\end{tabular}




\section{Conclusion}

This study focuses on two dimensions of Liberal Feminism i.e. Legal Equality and Political Awareness. Researcher took the sample of 335 girl students of higher education of different Universities. To see the difference among the girl students of Central, State and Private Universities, ANOVA test is used by the researcher. On the basis of the findings of this study it is concluded that there is difference in the reflection of Legal Equality as a dimension of Liberal Feminism among the girl students of Central, State and Private Universities. Girl students of Central and State University are significantly different from each other in the reflection of Legal Equality. Girl students of State and Private University are significantly different from each other in the reflection of Legal Equality while there is no significant difference between the girl students of Central and Private University in the reflection of Legal Equality. There is no significant difference in the reflection of Political Awareness as dimension of Liberal Feminism among the girl students of Central, State and Private Universities it means political awareness of all the girl students was almost same.

\section{References}

[1] Pachuri, G. (2009). Education in emerging India. Meerut: RLall Book Depot, 541.

[2] Vishwanathan, M. (1994). Development orientation of women's education. Jaipur: Rupa Offset Prienters, 191.

[3] Bhusan, B. (1989). Dictionary of sociology. New Delhi: Anmol publication, 98.

[4] Farley, J.E. (1990). Sociology. New Jersey: Prentice Hall, Englewood Cliffs, 168-170. 